\title{
Reengineering technology of specialized information systems
}

\section{Chyrkova Kateryna}

Kharkiv National University of Radio Electronics, 14 Nauky Ave, KharkivUA-61166, Ukraine, kateryna.chyrkova@nure.ua

\begin{abstract}
The subject of research is the process of reengineering the automated working places of specialized information systems of an organization. The technology of reengineering of specialized information systems is offered, which consists in the choice of organizational and technical structure of working places of staff taking into account the influence of the degree of automation of project decisions on the performance indicators of the organization. The use of the developed technology makes it possible to make rational choice of design solutions to increase the degree of automation of working places, which ensures improvement of the performance indicators by maximizing the completeness and reliability of data entry in the conditions of uncertain reengineering costs.
\end{abstract}

Keywords: specialized information system; automated working place; degree of automation; reliability of data; completeness of data; reengineering of information system.

\section{INTRODUCTION AND PROBLEM STATEMENT}

One of the mechanisms for improving the performance of the organization, and thus maintaining competitiveness is the development of an information system that provides information support for the business processes of the organization. Information systems provide data collection and data processing during the execution of business processes with varying degrees of automation, which affects the completeness and reliability of information of business processes information support. The completeness and reliability of data collection and processing is particularly critical for specialized information systems in which information support affects the quality of the end result, for example, related to human biological and infectious safety.

Accordingly, such specialized information systems need to be upgraded or reengineered in order to improve the indicators that evaluate the performance result of the organization. The need for reengineering or upgrading of specialized information of the system can be caused by the emergence of new vectors of development of the organization, the emergence of new regulatory requirements for business processes and new information technologies, the presence of initial errors in the design of specialized information system.

\section{PROBLEM SOLUTION AND RESUlTS}

At present, there are several concepts: reengineering, modernization, migration, evolution, restructuring of the information system, which in one way or another determine the improvement of the current information system [1].

Much attention is paying to the study of methods, models and technologies of reengineering or upgrading information systems that include the relevant phases or steps [2]. At the same time, there are no generally accepted methods, models and technologies of reengineering of specialized information system, which would provide determination of rational variant of organizational and technical structure of working places taking into account influence of degree of automation of workplaces on indicators of activity of organization and uncertainty of spending resources on reengineering.
The following technology is proposing for reengineering of specialized information system:

- decomposition of business processes of the subject area;

-decomposition of specialized information system into automated working places [3];

- determining the degree of automation of each working place [4];

- formation of datasets of information support of business processes with appropriate degrees of automation [5];

- identifying performance indicators that are affected by the completeness and reliability of the data collection;

- expert evaluation of the importance of datasets;

- determining the importance of each working place;

- formation of a table of impact of datasets on certain performance indicators of the organization;

- analysis of the functional structure of the specialized information system for compliance with the established requirements and standards;

- formation of many alternative variants of design decisions for working places;

- determination of partial performance indicators of each working place under the respective variant of the design decision and costs for modernization;

- selection of rational organizational and technical structure of the each working place according to the criterion [6].

\section{CONCLUSIONS}

It is advisable to use the proposed technology of reengineering of the specialized information system to increase the performance of the organization by modernizing the organizational and technical structure of the automated workplaces in the conditions of unspecified reengineering costs.

\section{REFERENCES}

[1] Yu. V. Doronina, V. O. Ryabovaya, "Metod modernizatsii informatsionnyih sistem ekologicheskogo monitoringa na osnove analiza ih funktsionalnoy nagruzki," Tr. SPIIRAN, vol 44, 2016, pp.133-152.

[2] М. С Сафонов, "Метод реінжинірингу інформаційної системи 3 використанням об'єктів управління," Електротехнічні та комп'ютерні системи, vol 13, 2014, pp. 105-113.

[3] А. В. Міхнова, Д.К. Міхнов, К.С. Чиркова, "Метод формування організаційно-технічних структур сегментів IC служби крові," наук. пр. Системи обробки інформаціі. - 2015. - № 12 (137). - С. $156-160$.

[4] A. Mikhnova, D. Mikhnov, K. Chyrkova, "Information support model of production transfusion processes," Eastern-European Journal of Enterprise Technologies, vol. 3/3 (81), 2016, pp. 36-43. DOI: 10.15587/1729-4061.2016.7167.

[5] А. В. Міхнова, Д.К. Міхнов, К.С. Чиркова, "Модель спеціалізованої медичної інформаційної системи," Вісник Кременчуцького національного університету імені Михайла Остроградського. Кременчук: КрНУ, vol 5(118), 2019, pp. 75-82. DOI: https://doi.org/10.30929/1995-0519.2019.5.75-82.

[6] A. Mikhnova, D. Mikhnov, K. Chyrkova, "Method for evaluating the efficiency of upgrading specialized information systems," Innovative technologies and scientific solutions for industries, vol. 4 (10), 2019, pp. 69-76. DOI: https://doi.org/10.30837/2522-9818.2019.10.069. 